\title{
PENINGKATAN HASIL BELAJAR IPA MATERI KENAMPAKAN RUPA BUMI MENGGUNAKAN MODEL SCRAMBLE
}

\author{
Metta Ariyanto \\ PGSD FKIP Universitas Kristen Satya Wacana \\ mettaari27@gmail.com
}

\begin{abstract}
This study aims to improve understanding of the concept visual appearance of the earth through media-assisted learning model Scramble picture cards in Class III Elementary Negeri Sumogawe Getasan District of Semarang District 03 school year 2016/2017. The shape of this research is classroom action research (PTK) are conducted in two cycles. Each cycle consists of four phases: planning, implementation, observation, and reflection. Subjects were students in third grade students of SD Negeri 03 Sumogawe Getasan District of Semarang District, amounting to 34 students consisting of 17 male students and 17 female students. Source data comes from teachers and students. Data collection techniques used were interviews, observation, testing, and documentation. Results of research conducted initial conditions prior to student learning improvement achieve mastery only 15 students (46.42\%), while 19 students $(53.57 \%)$ have not yet reached the thoroughness with an average value of 61.42. In the first cycle has been implementing assisted learning method scrambe picture card games increased student learning outcomes that achieve completeness limit of 20 students (64.28\%) and who have not completed 14 students (35.71\%) with an average value of 63.57. At this stage of the second cycle of the 34 students who achieve mastery of 30 students (89.28\%) who have not completed 4 students $(10.71 \%)$ and the average value KKM science subjects is 65 . Viewed from the repair cycle I and cycle II it can be concluded that this research is successful and does not need to continue the next cycle.
\end{abstract}

Keywords: Scramble learning model, the appearance of the surface of the earth, learning outcomes.

\section{PENDAHULUAN}

Pembelajaran IPA di SD, diupayakan adanya penekanan pada pembelajaran Salingtemas (Sains, lingkungan, teknologi, dan masyarakat) yang diarahkan pada pengalaman belajar yang lebih bermakna Depdiknas (dalam Citrasmi dkk, 2016). Depdiknas (dalam Andriana, 2014) menyatakan bahwa "Ilmu Pengetahuan Alam (IPA) berhubungan dengan cara mencari tahu tentang alam secara sistematis, dan IPA bukan hanya penguasaan kumpulan pengetahuan yang berupa fakta-fakta tetapi disertai dengan konsep-konsep, prinsipprinsip yang merupakan suatu proses penemuan. Maka dapat disimpulkan bahwa mata pelajaran IPA adalah mata pelajaran yang penting, yang mana pelajaran IPA dipelajari sejak pendidikan dasar, pelajaran IPA digunakan siswa untuk mempelajari hubungan manusia dengan alam dengan cara pengamatan dan pengumpulan konsepkonsep alam yang logis, sistematis dan bertujuan untuk sebuah penemuan.

Tujuan pembelajaran IPA di SD adalah pemahaman terhadap disiplin IPA dan keterampilan berkarya untuk menghasilkan suatu produk yang akan merefleksikan penguasaan kompetensi seseorang sebagai hasil belajarnya Sukra (dalam Citrasmi dkk, 2016). Maka terlihat pembelajaran IPA diorentasikan kepada aktivitas siswa dan guru yang mendukung konsep, prisip dan prosedur yang mendorong konsep pembelajaran yang bermakna untuk hasil yang memuaskan.

IPA merupakan pelajaran yang diterima sejak jenjang pendidikan dasar sampai dengan pendidikan menengah atas, adapun pengertian IPA menurut ahli, Permendiknas No. 22 tahun 2006 (dalam Suryanta dkk, 2014) menyatakan tentang Standar Isi mendifinisikan bahwa Ilmu Pengetahuan 
Alam (IPA) berkaitan dengan cara mencari tahu tentang alam secara sistematis, sehingga IPA tidak hanya berisi penguasaan kumpulan pengetahuan yang berupa faktafakta, konsep-konsep, atau prinsipprinsip saja tetapi juga merupakan suatu proses penemuan.

Menurut Samatowa (dalam Murti dkk, 2016) menyatakan bahwa Ilmu Pengetahuan Alam adalah aktivitas anak yang melalui berbagai kegiatan nyata dengan alam menjadi hal untama dalam pembelajaran IPA. Sedangkan menurut Damayanti (dalam Noorhafizah dan Asmawati 2014) mennyatakan bahwa pengembangan Ilmu Pengetahuan Alam sangat penting agar usaha pencapaian tujuan pembelajaran dapat dilakukan dengan efektif.

Dari pendapat ahli diatas dapat disimpulkan bahwa IPA adalah pelajaran yang mengharapkan siswa dapat terjun secara langsung dengan tahapan yang sistematis melalui berbagai macam tahapan logis, dan berujung pada sebuah penemuan baru mengenai alam demi tercapai tujuan pembelajaran yang efektif.

\section{Hasil Belajar}

Pengertian hasil menurut Purwanto (dalam Sukmadinata dalam Sukriswati, 2016) hasil belajar adalah merupakan ketercapaian tujuan pendidikan pada siswa yang mengukuti proses belajar mengajar, hasil belajar juga dapat diartikan perubahan yang diakibatkan manusia berubah dalam sikap dan tingkah lakuknya.

Menurut Sukmadinata (dalam Sukriswati, 2016) menyatakan bahwa hasil belajar merupakan realisasi atau pemekaran dari kecakapan-kecakapan potensi atau kapasitas yang dimiliki seseorang. Menurut Nana Sudjana (dalam Sukriswati, 2016) hasil belajar merupakan kemampuan- kemampuan yang dimiliki setelah ia menempuh pengalaman belajarnya (proses belajar mengajar).

Dari pendapat di atas dapat disimpulkan bahwa hasil belajar adalah perubahan berupa kecakapan fisik, mental, intelektual yang berproses dari kegiatan belajar baik di jenjang pendidikan formal seperti sekolah dan di jenjang pendidikan non formal seperti dilingkup keluarga dan masyarakat yang akan digunakan dalam kegiatan sehari- hari baik didalam sekolah maupun bermasyarakat.

Berdasarkan pengertian dan tujuan pembelajaran IPA maka guru perlu merancang pelajaran yang mendorong siswa untuk mempunyai rasa keinginan untuk mengikuti pembelajaran, menurut Damayanti (dalam Ramadani dkk, 2014) menyatakan bahwa kegiatan pelajaran haruslah menantang menyenangkan, mendorong eksplorasi memberi pengalaman sukses dan pengembangan kecakapan berfikir siswa. Oleh karena itu dalam proses pembelajaran IPA di SD haruslah menekankan keaktifan siswa, yang tidak hanya medengarkan ceramah dari guru, hal ini bertujuan untuk memberikan pengalaman yang lebih kepada siswa untuk menanamkan konsep- konsep pelajaran IPA dari pengalaman siswa itu sendiri.

\section{Model Pembelajaran Scramble}

Suyatno (dalam Lestari dkk, 2016), menyatakan bahwa model pembelajaran Scramble merupakan salah satu tipe pembelajaran yang disajikan dalam bentuk kartu dengan mencari pasangan jawaban dari pertanyaan yang jawabannya tersusun secara acak. Menurut Komalasari (dalam Lestari dkk, 2016), mengutarakan bahwa model Scramble ini mengajak siswa mencari jawaban terhadap suatu pertanyaan secara kreatif dengan menyusun huruf-huruf yang disusun secara acak.

Komalasari (Murti dkk, 2016) berpendapat bahwa "Model Pembelajaran Scramble yaitu model pembelajaran yang mengajak siswa mencari jawaban terhadap suatu pertanyaan atau pasangan dari suatu konsep secara kreatif dengan cara menyusun huruf-huruf yang disusun secara acak sehingga membentuk suatu jawaban atau pasangan konsep". Sedangkan menurut 
Suyatno (dalam Murti dkk, 2016) berpendapat bahwa "Model Pembelajaran Scramble adalah suatu metode pembelajaran yang menggunakan kartu soal dan kartu jawaban yang dipasangkan atau diurutkan menjadi urutan logis. Sehingga siswa dituntut berpikir kreatif dalam pembelajaran di dalam kelas, untuk dapat mengurutkan kata-kata dalam kunci jawaban menjadi kata yang logis".

Dari pendapat di atas dapat disimpulkan bahwa model pembelajaran Screamble adalah model pembelajaran dengan cara berkelompok dengan mengasah kekreatifitasan siswa untuk mencari jawabanjawaban logi dari kata-kata yang diacak dan siswa diminta merangkai menjadi jawaban yang logis dari sebuah pertanyaan atau persolan.

Suyatno (dalam Suryanta dkk, 2014) adapun sintaks model pembelajaran Scramble yaitu: (1) buatlah kartu soal sesuai bahan ajar; (2) Buatlah kartu soal dengan diacak nomornya; (3) sajikan materi; (4) membagikan kartu soal pada kelompok dan kartu jawaban; (5) siswa bekelompok mengerjakan soal dan mencari jawaban yang benar.

Hasil temuan di SDN Sumogawe $03 \mathrm{Kab}$. Semarang menunjukkan bahwa hasil belajar IPA siswa masih tergolong kurang memuaskan. Permasalahan ini merupakan salah satu indikator bahwa proses pembelajaran IPA di sekolah belum maksimal, hasil observasi peneliti sebelum tindakan KKM di SDN Sumogawe 03 adalah 65, hasil belajar siswa sebelum tindakan siklus I dapat terdapat $15(44,11 \%)$ siswa yang belum tuntas dan $19(55,88 \%)$ siswa telah tuntas KKM dengan jumlah siswa keseluruhan 34 siswa. Berdasarkan latar belakang masalah dalam pelajaran IPA ini guru bersama peneliti mengadakan penelitian tindakan kelas untuk meningkatkan hasil belajar siswa menggunakan model pembelajaran kooperatif tipe scramble.

Model pembelajaran Scramble menurut ahli antara lain diutaran oleh Soeparno (dalam
Ramadani dkk, 2014) menyatakan, bahwa model pembelajaran Scramble adalah pembelajaran secara berkelompok dengan mencocokan kartu pertanyaan dan kartu jawaban yang telah disediakan.

Berdasarkan pengertian model pembelajaran Scramble model pembelajaran ini bertujuan untuk mengubah pola proses pembelajaran yang semula hanya berpusat kepada guru, akan diubah menjadi pola belajar yang berpusat pada siswa yang mengutamakan interaksi siswa dalam kelompok- kelompok kecil didalam proses pembelajaran dengan tujuan untuk meningkatkan hasil belajar siswa, olehkarena itu peneliti mengangkat rumusan masalah “ apakah dengan menggunakan model pembelajaran Scramble dapat meningkatkan hasil belajar siswa pada mata pelajaran IPA pada materi kenampakan rupa bumi?", dan peneliti mengangkat judul penelitian " Peningkatan Hasil Belajar IPA Materi Kenampakan Rupa Bumi Menggunakan Model Scramble".

Adapun penelitian terdahulu yang sejalan dengan penelitian ini antara lain penelitian yang dilakukan oleh Lestari (2015) menyatakan bahwa hasil penelitian menggunakan model pembelajaran Scramble pada mata pelajaran IPA di kelas V di SDN 101766 Bandar Setia menyatakan adanya peningkatan hasil belajar siswa yang berjumlah 30 orang siswa. Kondisi pre tes siswa tuntas sebanyak 7 orang atau $(23,3 \%)$ dan yang tidak tuntas sebanyak 23 orang atau (76\%) dengan rata- rata kelas $(51,33 \%)$. Setelah tindakan siklus I tingkat ketuntasan meningkat menjadi 28 siswa $(93,3 \%)$ yang tidak tuntas sebanyak 2 siswa $(6,6 \%)$ dengan rata- rata 87,66. Peningkatan hasil belajar dari keadaan awal (pre tes dan tindakkan siklus I meningkat sebesar $(56,67 \%)$ dan tindakkan siklus I ke siklus II sebesar (13,3\%). Hasil observasi guru diperoleh pada siklus I pertemuan pertama dengan menggunakan model pembelajaran Scramble rata- rata 71,87tergolong tinggi tindakan siklus II 
pertemuan kedua diperoleh rata- rata nilai 90,63 tergolong tinggi.

\section{METODE PENELITIAN}

Penelitian ini merupakan Penelitian Tindakan Kelas (PTK). Sanjaya (dalam Hafizah, 2014) mengemukakan bahwa Penelitian Tindakan Kelas adalah penelitian yang di dalamnya ada intervensi atau perlakuan tertentu untuk perbaikan kinerja dalam dunia nyata.

Adapun tujuan dati Penelitian Tindakan Kelas menurut Trianto (dalam Hafizah, 2014) Tujuan dari PTK secara umum adalah sebuah peningkatan atau perbaikan (improvement and therapy), anatara lain sebagi berikut: (1) Peningkatan atau perbaikan terhadap kinerja belajar siswa di sekolah; (2) Peningkatan atau perbaikan terhadap mutu proses pembelajaran di kelas; (3) Peningkatan atau perbaikan terhadap kualitas penggunaan media, alat bantu ajar, dan sumber belajar lainnya; (4) Peningkatan atau perbaikan terhadap kualitas prosedur dan alat evaluasi yang digunakan untuk mengukur proses dan hasil belajar siswa; (5) Peningkatan atau perbaikan terhadap masalah masalah pendidikan anak di sekolah; (6) Peningkatan dan perbaikan terhadap kualitas penerapan kurikulum dan pengembangan kompetensi siswa di sekolah.

Menggunakan metode penelitian Penelitian Tindakan Kelas yang terdiri dari dua siklus yang dikemukakan oleh Kemmis dan Taggart (dalam Andriani, 2011) yang terdiri dari 4 langkah, antara lain: 1) Perencanaan. Pada tahap ini peneliti menyiapkan instrument penelitian yang terdiri dari instrument pembelajaran, instrument observasi dan instrument penilaian hasil belajar siswa; 2) Pelaksanaan. Semua yang telah dipersiapkan pada tahap perencanaan akan dilaksanakan pada tahap ini; 3) Observasi semua kegiatan yang terjadi selama pelaksanaan diamati dan dicatat; 4) Refleksi. Dari hasil pengamatan dapat lihat kekurangan yang terjadi selama pelaksanaan sehingga pada siklus berikutnya dapat dilakukan penyempurnaan.

Jadi Penelitian Tindakan Kelas adalah penelitian yang dilakukan oleh guru kelas dan memperoleh permasalahan yang diperoleh didalam kelas dan diselesaikan didalam kelas secara tersetruktur sesuai dengan langkahlangkah PTK dan hasil pemecahan masalah dapat dipergunakan untuk meningkatkan kecakapan kinerja guru di sekolah.

\section{HASIL DAN PEMBAHASAN}

Penelitian ini berjenis Penelitian Tindakan Kelas yang mana dilaksanakan dua siklus. Penelitian ini bertjuan untuk mengukur tingkat peningkatan hasil belajar siswa atau tingkat kognitif siswa, adapun hasil belajar siswa pada kondisi awal siswa diperoleh dari guru kelas pada mapel IPA siswa yang belum tuntas $15(44,11 \%)$ dan $19(55,88 \%)$ siswa telah tuntas KKM dengan jumlah siswa keseluruhan 34 siswa. Berdasarkan hasil observasi peneliti pada pra siklus peneliti bersama guru kelas bekerja sama untuk merencanakan proses tindakan siklus I.

Pada kondisi awal tingkat ketuntasan siswa mencapai 16 siswa atau $(47,05 \%)$ dan 18 siswa atau $(52,94 \%)$ belum mencapai KKM. Nilai pra siklus dapat dilihat pada Tabel 1.

Tabel 1. Distribusi Frekuensi Pra Siklus Nilai Mata Pelajaran IPA

\begin{tabular}{cccc}
\hline & \multicolumn{3}{c}{ Pra siklus } \\
\cline { 2 - 4 } No & Nilai & $\begin{array}{c}\text { Jumlah } \\
\text { siswa }\end{array}$ & $\begin{array}{c}\text { Persent } \\
\text { ase }\end{array}$ \\
\hline 1 & Tuntas & 16 & $47,05 \%$ \\
\hline 2 & $\begin{array}{l}\text { Belum } \\
\text { Tuntas }\end{array}$ & 18 & $52,94 \%$ \\
\hline
\end{tabular}

Berdasarkan hasil belajar siswa pada kondisi pra siklus peneliti dan guru kelas melaksanakan perencanaan untuk proses tindakan siklus I. Setelah tindakan siklus I terdapat kenaikan tingkat ketuntasan siswa, pada tindakan siklus I siswa yang tuntas berjumlah 24 siswa atau $(70,58 \%)$ dan siswa yang belum tuntas berjumlah 10 siswa atau 
$(24,41 \%)$. Hasil tindakan siklus I dapat diihat pada Tabel 2.

Tabel 2. Distribusi Frekuensi Siklus I Nilai Mata Pelajaran IPA

\begin{tabular}{cccc}
\hline \multirow{2}{*}{ No } & \multicolumn{3}{c}{ Siklus I } \\
\cline { 2 - 4 } & Nilai & $\begin{array}{c}\text { Jumlah } \\
\text { siswa }\end{array}$ & $\begin{array}{c}\text { Persenta } \\
\text { se }\end{array}$ \\
\hline 1 & Tuntas & 24 & $70,58 \%$ \\
\hline 2 & $\begin{array}{l}\text { Belum } \\
\text { Tuntas }\end{array}$ & 10 & $24,41 \%$ \\
\hline
\end{tabular}

Berdasarkan hasil penelitian kondisi pra siklus dan tindakan siklus I dapat disajikan dalam Tabel 3,

Tabel 3. Perbandingan Distribusi Frekuensi Nilai Mata Pelajaran IPA Pra Siklus dan Siklus I

\begin{tabular}{cccccc}
\multicolumn{4}{c}{ Mata Pelajaran IPA Pra Siklus dan Siklus I } \\
\hline \multirow{2}{*}{ No } & \multirow{2}{*}{ Nilai } & \multicolumn{2}{c}{ Pra siklus } & \multicolumn{2}{c}{ Siklus I } \\
\cline { 3 - 6 } & & $\begin{array}{c}\text { Jumlah } \\
\text { siswa }\end{array}$ & $\begin{array}{c}\text { Persent } \\
\text { ase }\end{array}$ & $\begin{array}{c}\text { Jumlah } \\
\text { Siswa }\end{array}$ & $\begin{array}{c}\text { Persent } \\
\text { ase }\end{array}$ \\
\hline 1 & Tuntas & 11 & $36,60 \%$ & 18 & $60,00 \%$ \\
\hline 2 & $\begin{array}{c}\text { Belum } \\
\text { Tuntas }\end{array}$ & 19 & $63,30 \%$ & 12 & $40,00 \%$ \\
\hline
\end{tabular}

Berdasarkan permasalahan yang muncul pada tndakan siklus I peneliti bersama dengan guru menyusun rencana untuk pemecahan masalah yang muncul pada siklus I dan diterapkan langsung pada siklus II guna untuk meminimalisir permasalahan- permasalahan yang akan muncul pada siklus II.

Pada tindakan siklus II tingkat ketuntasan siswa meningkat kembali sehingga tingkat ketuntasan siswa mencapai 31 siswa atau $(89,28 \%)$ dan siswa yang belum mencapai KKM berjumlah 3 siswa atau $(10,7 \%)$, dari tindakan pada siklus II dapat disajikan dalam Tabel 4.

Tabel 4. Distribusi Frekuensi Nilai Mata Pelajaran IPA Siklus II

\begin{tabular}{cccc}
\hline & \multicolumn{3}{c}{ Siklus II } \\
\cline { 2 - 4 } & Nilai & $\begin{array}{c}\text { Jumlah } \\
\text { siswa }\end{array}$ & Persentase \\
\hline 1 & Tuntas & 31 & $89,28 \%$ \\
\hline 2 & $\begin{array}{c}\text { Belum } \\
\text { Tuntas }\end{array}$ & 3 & $10,70 \%$ \\
\hline
\end{tabular}

Berdasarkan Tabel 3 dapat disimpulkan bahwa ada kenaikan tingkat ketuntasan siswa, pada kondisi pra siklus tingkat ketuntasan hanya mencapai 16 siswa atau $(47,05 \%)$ dan pada siklus I tingkat ketuntasan mencapai 24 siswa atau $(70,58 \%)$ jadi dapat disimpulkan bahwa tingkat ketuntasan siswa meningkat 8 siswa atau $(23,52 \%)$, dan tingkat ketidak tuntasan siswa menurun sebesar 8 siswa $(23,52 \%)$ dari jumlah keseluruhan siswa 34 siswa.

Dari tindakan siklus I terdapat kenaikan tingkat ketutasan hasil belajar siswa yang cukup memuaskan, akan tetapi dalam proses tindakan siklus I tidak lepas dari permasalahan. Permasalahan yang muncul pada tindakan siklus I antara lain guru dan siswa belum memahami jalannya proses pembelajaran menggunakan model pembelajaran Scramble sehingga guru dan siswa masih kebingungan dalam pelaksanaan pembelajaran, suasana proses pembelajaran kurang kondusif dikarenakan siswa yang rame, masih terdapat siswa yang belum mecapai KKM.
Hasil tindakan siklus I dan II dapat disajikan dalam bentuk Tabel 5 sebagai berikut,

Tabel 5. Perbandingan Distribusi Frekwensi Nilai Mata Pelajaran IPA Siklus I dan Siklus II

\begin{tabular}{cccccc}
\hline \multirow{2}{*}{$\begin{array}{c}\mathrm{N} \\
\mathrm{o}\end{array}$} & \multirow{2}{*}{ Nilai } & \multicolumn{2}{c}{ Siklus I } & \multicolumn{2}{c}{ Siklus II } \\
\cline { 3 - 6 } & & $\begin{array}{c}\text { Jumlah } \\
\text { siswa }\end{array}$ & $\begin{array}{c}\text { Persent } \\
\text { ase }\end{array}$ & $\begin{array}{c}\text { Jumlah } \\
\text { Siswa }\end{array}$ & $\begin{array}{c}\text { Persent } \\
\text { ase }\end{array}$ \\
\hline 1 & Tuntas & 24 & $70,58 \%$ & 31 & $89,28 \%$ \\
\hline 2 & $\begin{array}{c}\text { Belum } \\
\text { Tuntas }\end{array}$ & 10 & $24,41 \%$ & 3 & $10,70 \%$ \\
\hline
\end{tabular}

Dari Tabel 5 mengenai perbandingan distribusi frewensi siklus I dan siklus II dapat disimpulkan bahwa terdapat kenaikan tingkat ketuntasan hasil belajar siswa dari tindakkan siklus II, pada siklus I tingkat ketuntasan siswa mencapai 24 siswa atau $(70,58 \%)$ dan pada tindakkan pada siklus II tingkat ketuntasan mencapai 31 siswa atau $(89,28 \%)$ kenaikan hasil belajar siswa mencapai 7 siswa atau $(20,58 \%)$ dan tingkat ketidak tuntasan siswa menurun sebesar 7 siswa atau $(20,58 \%)$.

Dari tindakkan pada siklus II permasalahan yang muncul pada siklus I dapat 
teratasi dengan baik, dan tingkat ketuntasan siswa kembali meningkat pada siklus II. Akantetapi pada siklus II ini tidak lepas dari permasalahan, permasalahan yang muncul antara lain adalah masih terdapat 3 siswa yang tidak tuntas KKM atau $(8,82 \%)$. Nilai pra siklus, siklus I dan siklus II dapat dilihat pada Tabel 6

Tabel 6. Perbandingan Distribusi Frekwensi Nilai Mata Pelajaran IPA Pra Siklus, Siklus I, Siklus II

\begin{tabular}{cccccccc}
\hline & \multicolumn{2}{c}{ Pra siklus } & \multicolumn{2}{c}{ Siklus I } & \multicolumn{2}{c}{ Siklus II } \\
\cline { 3 - 8 } N & Nilai & Jum & \multicolumn{3}{c}{ Juml } & \multicolumn{3}{c}{ Juml } \\
o & lah & Persen & ah & Persen & ah & Persent \\
& & sisw & tase & sisw & tase & Sisw & ase \\
& & a & & a & & a & \\
\hline
\end{tabular}

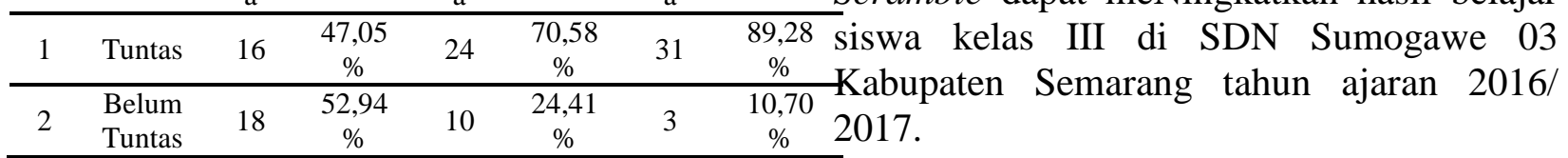

Berdasarkan tabel perbandingan distribusi frekwensi nilai mata pelajaran IPA siswa kelas III sdn sumogawe 03 tahun ajaran 2016/ 2017 dari kondisi pra siklus, siklus I dan siklus II dapat disimpulkan bahwa penelitian ini telah berhasil dilaksanakan dan telah berhasil memecahkan rumusan masalah yang ditentukan oleh peneliti oleh karena itu peneliti memutuskan menghentikan penelitian pada siklus II, dengan hasil kondisi pra siklus dan ke tindakan siklus I tingkat kentuntasan siswa meningkat sebesar 8 siswa atau $(23,52 \%)$, siklus I ke Siklus II meningkat kembali sebesar 7 siswa atau (20,58\%) sehingga pada tindakan siklus II tingkat ketuntasan mencapai 31 anak atau $(82,28 \%)$.

Berdasarkan dari penelitian ini maka dapat disimpulkan bahwa model pembelajaran Scramble dapat meningkatkan hasil belajar IPA SDN Sumogawe kelas III dengan materi kenampakan rupa bumi, oleh karena itu peneliti menyarankan untuk para pendidik atau pihak sekolah untuk selalu berani berinovasi dalam menyampaikan materi ajar kepada siswa, supaya dapat memperoleh hasil belajar siswa yang memuaskan.

\section{SIMPULAN}

Berdasarkan hasil penelitian terhadap hasil belajar siswa dalam mata pelajaran IPA dalam materi rupa bumi maka dapat disimpulkan bahwa model pembelajaran Scramble dapat meNingkatkan hasil belajar 2017.

Hasil penelitian kondisi pra siklus hasil belajar siswa pada mata pelajaran IPA tingkat ketuntasan hanya mencapai 16 siswa atau $(47,05 \%)$ dan tingkat ketidak tuntasan siswa mencapai 18 siswa atau $(52,41 \%)$. Hasil dari tindakan siklus I tingkat katuntasan meingkat menjadi 24 siswa atau $(70,58 \%)$ dan tingkat ketidak tuntasan sebesar 10 siswa atau $(24,41 \%)$ dan pada tindakan siklus II ketuntasan hasil belajar siswa kembali mengalami kenaikan sehingga mencapai 31 siswa atau $(89,28 \%)$ dan ketidak tuntasan siswa hanya mencapai 3 siswa atau $(10,70 \%)$. Berdasarkan hasil penelitian ini dapat disimpulkan bahwa model pembelajaran Scramble dapat meingkatkan hasil belajar siswa kelas III di SDN Sumogawe 03 Kabupaten Semarang.

\section{DAFTAR PUSTAKA}

Andriana, Wahyu Istanti dan H.A. Triwidjaja. 2014. Penerapan Model Pembelajaran Picture And Picture Pada Pembelajaran Ipa Anak Tunagrahita SDLB. Jurnal P3LB, 1 (2): 169174. 
Andriani, Lis. 2011. Meningkatkan Hasil Belajar Siswa Pada Pelajaran IPA Dengan Penerapan Model Pembelajaran kooperatif Tipe Picture To Picture Di Kelas V SDN 2 Balaesang. Jurnal Kreatif Tadulako Online. 6 (5): 1-10.

Citrasmi Ni Wyn, dkk. 2016. Pengaruh Model Pembelajaran Scramble Berbantuan Media Gambar Terhadap Hasil Belajar Ipa Di Sd. E-jurnl Undiksha, 4 (1): 1-10.

Lestari, Dewi dan Demmu Koro- Koro. 2015. Meningkatkan Hasil Belajar Siswa Pada Mata Pelajaran Ipa Dengan Menggunakan Model Pembelajaran Scramble Di Kelas V Sd Negeri No. 101766 Bandar Setia. Jurnal.Unimed. 3 (1): 1-9.

Lestari, Ni Kadek Sri, dkk. 2016. Penerapan Model Pembelajaran Scramble Untuk Meningkatkan Keaktifan Dan Hasil Belajar Ipa Pada Siswa Kelas Iv. E-jurnal.PGSD, 4 (1): 1-10.

Murti, I Gede Ari dkk. 2016. Pengaruh Model Pembelajaran Scramble Berbantuan Media Gambar Terhadap Hasil Belajar Ipa Siswa Kelas Iv Sd. e-Junal PGSD Universitas Pendidikan Ganesha Jurnal PGSD, 9 (1): 1-11.

Noorhafizah dan Asmawati. 2014. Meningkatkan Hasil Belajar Konsep Energi Panas Melalui Model Pembelajaran Inkuiri Terbimbing Variasi Model Student Teams Achievement Divisions (Stad) Pada Siswa Kelas Iv Sdn Teluk Dalam 3 Banjarmasin. Jurnal.fkip.uns.ac.id.Jurnal Paradikma, 9 (2): 1-4.

Ramadani Ni Km Triana, dkk. 2014. Pengaruh Model Pembelajaran Scramble Berbantuan Kartu Pertanyaan Terhadap Hasil Belajar Ipa Siswa Kelas V Sd. Ejurnal.Undiksh, 2 (1): $1-10$.

Ramadani, Ni Km Triana, dkk. 2014. Pengaruh Model Pembelajaran Scramble Berbantuan Kartu Pertanyaan Terhadap Hasil Belajar Ipa Siswa Kelas V Sd. Jurnal PGSD, 2 (1): $1-10$.

Suryanta, I Made, dkk. 2014. Pengaruh Model Pembelajaran Scramble Berbantuan Media Gambar Animasi Terhadap Hasil Belajar Ipa Siswa Kelas V Sd Gugus Yos Sudarso Denpasar. E-jurnal.Undiksha, 2 (1): 1-10. 